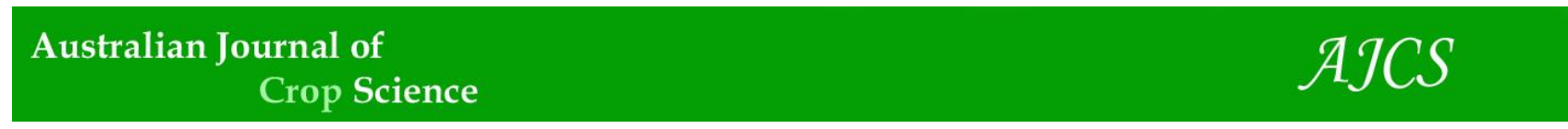

AJCS 10(6):793-798 (2016)

ISSN:1835-2707

DOI: $10.21475 /$ ajcs.2016.10.06.p7283

\title{
Volatilization of ammonia in stabilized slow-release nitrogen fertilizer under controlled conditions
}

\author{
Vinícius José Ribeiro ${ }^{1 *}$, Felipe Vaz Andrade ${ }^{2}$, Carlos Henrique Eiterer de Souza ${ }^{3}$ and Eduardo Sá \\ Mendonça $^{2}$
}

\author{
${ }^{1}$ Soil Department, University Federal of Viçosa-UFV, Viçosa, MG, Brazil \\ ${ }^{2}$ Department of Plant Production, University Federal of Espírito Santo-UFES, Alegre, ES, Brazil \\ ${ }^{3}$ University Center of Patos de Minas-UNIPAM, Patos de Minas, MG, Brazil
}

\author{
*Corresponding author: vj.ribeiro@yahoo.com.br (V. J. Ribeiro)
}

\begin{abstract}
The loss of nitrogen through volatilization leads research to the search for new technologies that release nutrients in a manner synchronized with the crop demand, minimizing losses and increasing efficiency of its use in agriculture, as is the case with the stabilized slow-release nitrogen fertilizer. This work sought to evaluate the losses of volatilized $\mathrm{N}_{-} \mathrm{NH}_{3}$ in stabilized slow-release nitrogen fertilizer applied to the soil. The treatments followed a $5 \times 3 \times 2$ factorial as follows: five nitrogen fertilizer sources (conventional urea - CU; urea combined with zeolite - UZ; sulfur coated urea - US; NBPT coated urea - $\mathrm{U}_{\mathrm{NBPT}}$, and urea combined with organic material - OU); three application times; and two managements (surface and incorporated applications) with three replications. The experiment was conducted using a collection chamber to capture $\mathrm{NH}_{3}$ for 25 days, with samples taken at 2, 4, 7, 9, $11,14,16,18,21,23$ and 25 days after the start of the experiment. The ascending order of $\mathrm{N}_{-} \mathrm{NH}_{3}$ volatilization was: $\mathrm{UZ}<\mathrm{US}<\mathrm{CU}$ $<\mathrm{U}_{\mathrm{NBPT}}<\mathrm{OU}$, regardless of the time and management adopted. For all the sources used there was a loss reduction from $20.45 \%$ to $12.29 \%$, when $\mathrm{N}$ sources were parceled, and from $19.63 \%$ to $13.95 \%$ when they were incorporated.
\end{abstract}

Keywords: nitrogen fertilization; $\mathrm{N}$ losses; $\mathrm{NH}_{3}$ release; coated urea.

Abbreviations: Ca_calcium; Mg_magnesium; K_potassium; P_phosphorus; N_nitrogen; H + Al_acidity potential; CEC_cation exchange capacity; $\mathrm{NH}_{3 \_}$ammonia; $\mathrm{CU}$ _convencional ureia; UZ_urea combined with mineral zeolite; US_elemental sulfur coated

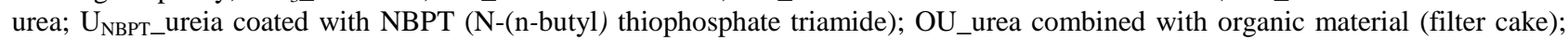
T1_Time1; T2_Time2; T3_Time3; IM_Incorporated management; SM_Surface management.

\section{Introduction}

The integration of technology is assuming an important role in helping farmers in the management of factors produced in the field. Each segment, be it agricultural mechanization, biotechnology, or product efficiency, is enabling production improvements, creating a link between the primary sector, science and industry (Kreimeyer, 2015). This approach is ensuring many positive results, particularly by increasing the efficiency in the use of nitrogen fertilizers (Fernandes et al., 2005). The management of nitrogen fertilizer is one of the most studied agricultural practices in order to improve its use efficiency (Cantarella et al., 2008; Frazão et al., 2014). This need exists because of the low efficiency of nitrogen fertilization, due to losses by leaching, denitrification and mainly via volatilization, losses which can reach over $70 \%$ (Lara Cabezas et al., 1997), especially under tropical conditions. New technologies have been adopted in order to minimize the losses of ammonia $\left(\mathrm{NH}_{3}\right)$ through volatilization. The principal one is the use of urea as a coating (covering) with chemically altered products and, or pellets (Bennett, 1996). Sato and Morgan (2008) observed that the N loss to the environment may be reduced with the use of coated fertilizers, corroborating Medina et al. (2008). According to these authors, the coated fertilizers offer low $\mathrm{N}$ volatilization (10 to $30 \%$ ) when compared to the conventional fertilizers.
However, contradictory results can be found in the literature, indicating advantages in the use of polymer coated urea (Wang et al., 2015; Nash et al., 2015) and others that report low efficiency compared with the common urea (Cahill et al., 2010; Carneiro et al., 2014). This study was conducted in order to quantify the $\mathrm{N}$ volatilized as $\mathrm{NH}_{3}$ after application of higher efficiency nitrogen fertilizer at different times and under different soil application managements.

\section{Results and Discussion}

The use of stabilized controlled release nitrogen $(\mathrm{N})$ fertilizers affected the amounts of $\mathrm{NH}_{3}$ volatilized since its application in the soil samples (Table 1), as demonstrated by contrasts C1, C2 and C3 (Table 2), as well as by the different application times and managements studied. When calculating the total amount of $\mathrm{N}-\mathrm{NH}_{3}$ lost via volatilization for the applied sources (Table 1) the following order of $\mathrm{N}$ $\mathrm{NH}_{3}$ volatilized was observed: $\mathrm{UZ}<\mathrm{US}<\mathrm{CU}<\mathrm{U}_{\mathrm{NBPT}}<$ OU. The values lost by volatilization were, respectively, $14.12 \%$ (or $5.30 \mathrm{mg} \mathrm{ring}^{-1}$ ); $15.12 \%$ (or $5.67 \mathrm{mg} \mathrm{ring}^{-1}$ ); $15.58 \%$ (or $5.85 \mathrm{mg} \mathrm{ring}^{-1}$ ); $16.41 \%$ (or $6.16 \mathrm{mg} \mathrm{ring}^{-1}$ ); $22.70 \%$ (or $8.52 \mathrm{mg} \mathrm{ring}^{-1}$ ). 
The form of the product combinations or coatings with urea may lead to a lower $\mathrm{N}$ release rate and therefore reduce its losses by volatilization. The values of volatilized $\mathrm{NH}_{3}$ observed are consistent with those reported in the literature by several authors (Volk, 1959; Lara Cabezas et al., 1997; Wang et al., 2015; Nash et al., 2015). The average values for loss-via-volatility were greater in the stabilized controlled release fertilizer group when compared to the use of conventional urea $(\mathrm{C} 1$, Table 2$)$. The explanation rests in the high $\mathrm{N}$ losses with the application of $\mathrm{OU}$ and $\mathrm{U}_{\mathrm{NBPT}}$ fertilizers, which increased the average above the levels when compared to the CU. The OU fertilizer used volatilized 2.67 $\mathrm{mg} \mathrm{ring}^{-1}$, equivalent to $7.12 \%$ more than CU (Table 2). These results reinforce the need for more studies on these new coating technologies related to the effect of the reduction of volatilized $\mathrm{N}-\mathrm{NH}_{3}$ loss, considering the type of coating, its quality and thickness and control of the experimental environment, such as temperature and soil moisture, among others. Khalil et al. (2006) found lower $\mathrm{N}$ losses through volatilization with an increase in the size of the fertilizer granules. However, research has also showed an increase in the $\mathrm{N}$ volatilization with increasing granule size (Lara Cabezas et al., 1992). The application of urea promoted a volatilization of $15.58 \% \mathrm{~N}^{-\mathrm{NH}_{3}}$ (5.85 mg ring ${ }^{-1}$, Table 2$)$. A similar result was observed by Peng et al. (2015), who obtained losses of up to $18 \%$ for urea. Kiehl and Sengik (1995) found volatilized $\mathrm{N}-\mathrm{NH}_{3}$ loss for urea reaching approximately $16 \%$ in sandy soil and $12 \%$ in clay soil. According to Connell et al. (1979), the N dose applied also has an effect on the $\mathrm{NH}_{3}$ losses by volatilization. The authors observed increased volatilization from $19 \%$ to $36 \%$ when the urea dose varied from 100 to $150 \mathrm{mg} \mathrm{dm}^{-3} \mathrm{~N}$.

For Almeida and Sanchez (2013) the use of controlled slow release $\mathrm{N}$ fertilizer is an alternative to reduce $\mathrm{N}$ loss. However, Zavaschi et al. (2014) in an assessment of $\mathrm{N}$ losses, noted that the application polymer coated urea did not reduce ammonia loss by volatilization and did not interfere in soil ammonium and nitrate levels. The use of the urease inhibitors does not necessarily lead to lower $\mathrm{NH}_{3}$ losses, only causing delays in the peak volatilization (Tasca et al., 2011).

Stafanato et al. (2013) evaluated the effectiveness of urea with associated technologies, and found a reduction of approximately $54 \%$ in $\mathrm{N}-\mathrm{NH}_{3}$ losses by volatilization when compared with the loss caused by commercial urea.

When comparing the OU fertilizer with other technologies, (Contrast $\mathrm{C} 2$, Table 2) $\mathrm{NH}_{3}$ loss showed a significant and positive value, resulting in an increased $\mathrm{NH}_{3}$ volatilization by the OU fertilizer. The OU fertilizer volatilized $8.52 \mathrm{mg} \mathrm{ring}^{-1}$, equivalent to $22.70 \%$, being the source that volatilized the most $\mathrm{NH}_{3}$ into the environment.

For Bono et al. (2006) the organomineral fertilizers can be used in a single application at planting as the $\mathrm{N}$ is concentrated in the mineral and organic form, this mineral $\mathrm{N}$ being absorbed quickly, and the organic $\mathrm{N}$ present in the organic fertilizer released throughout the crop cycle. As the organic $\mathrm{N}$ needs to be mineralized in the soil to be utilized by plants in nitric or ammoniacal forms, it remains in the soil longer (Bono et al., 2006). However, these results do not corroborate those found in the present study, in which the OU underwent higher losses than the use of $\mathrm{CU}$, indicating that the studied OU fertilizer is not an efficient source for reducing the $\mathrm{N}-\mathrm{NH}_{3}$ loss in the soil.

Comparing the chemical coating $\left(\mathrm{U}_{\mathrm{NBPT}}\right)$ and the physical coating technologies (US and UZ) (Contrast C3, Table 2), it was observed that losses by $\mathrm{N}-\mathrm{NH}_{3}$ volatilization of fertilizer $\mathrm{U}_{\mathrm{NBPT}}$ were higher than for other sources. For the experimental conditions of this study (temperature, soil moisture and soil type), the physical coatings were more efficient in reducing $\mathrm{N}$ losses in relation to chemical coatings. Carmona et al. (1990) reported that the use of the NBPT may not be able to completely control the $\mathrm{N}-\mathrm{NH}_{3}$ loss, because this type of coating does not withstand temperatures between 25 to $32^{\circ} \mathrm{C}$. According to the authors these temperatures favor the hydrolysis of urea and over time there is a decrease in the concentration of the inhibitor. This may result in a $\mathrm{U}_{\mathrm{NBPT}}$ fertilizer efficiency loss, because of the higher soil temperatures in tropical environments.

In Contrast, in the $\mathrm{C} 4$ treatment (Table 3), which compares the nitrogenous fertilizer US and UZ, the UZ was superior, resulting in less $\mathrm{N}-\mathrm{NH}_{3}$ volatilization. Thus, the UZ was the nitrogenated fertilizer that presented the lowest amounts of $\mathrm{N}$ volatilized as $\mathrm{NH}_{3}$, only $14.12 \%$ (5.30 mg ring ${ }^{-1}$ ). For Torma et al. (2014) nitrogenous fertilizer, combined with mineral zeolite, can be used in agriculture as a soil conditioner due to its high element retention capacity (elements like nitrogen, phosphorus and potassium, in addition to water), releasing them slowly, and it may reduce nitrate $\left(\mathrm{NO}_{3}{ }^{-}\right)$leaching losses and $\mathrm{NH}_{3}$ volatilization. One should also consider the reduced accessibility that microorganisms have to the $\mathrm{NH}_{4}{ }^{+}$adsorbed on the zeolite structure, preventing the transformation of $\mathrm{NH}_{4}{ }^{+}$into $\mathrm{NO}_{3}{ }^{-}$and reducing nitrogen losses (Mumpton, 1999).

The ability of zeolite to significantly reduce losses by volatilization makes its use as a new technology for more efficient urea-based fertilizer relevant, when it is applied in coverage. Werneck (2008) found a $20 \%$ decrease in $\mathrm{N}$ losses by volatilization when using a urea/zeolite mixture compared to conventional urea.

According to Yang et al. (2011), volatilization of $\mathrm{NH}_{3}$ from the sulfur-coated nitrogen fertilizer depends on the thickness of the coating (capsule) in relation to the granule size, because the total $\mathrm{N}$ content of urea coated with sulfur can decrease from $46 \%$ to 30 to $42 \%$. However, nutrients in sulfur coated fertilizers can be released quickly, in less than 3 months (Trenkel, 2010).

Regarding the $\mathrm{N}$ application form, all sources used in this study had higher $\mathrm{N}-\mathrm{NH}_{3}$ losses when applied to the soil surface, compared to their incorporated application $(2-3 \mathrm{~cm}$ deep) (Table 3). Soil surface application of nitrogen fertilizer led to $19.62 \%$ volatilization $\left(7.36 \mathrm{mg}^{\mathrm{ring}^{-1}} \mathrm{~N}^{-\mathrm{NH}_{3}}\right.$ ) on average, and incorporated, $13.94 \%$ of the total applied (5.23 mg ring ${ }^{-1}$ of $\mathrm{N}-\mathrm{NH}_{3}$ ). The incorporation reduces the $\mathrm{NH}_{3}$ losses by volatilization. The incorporation of the $\mathrm{N}$ virtually eliminates $\mathrm{NH}_{3}$ volatilization (Rodrigues and Kiehl, 1986; Silva et al., 1995; Lara Cabezas et al., 2000) because it enhances the contact between the fertilizer and the soil, favoring the adsorption of $\mathrm{NH}_{4}{ }^{+}$to the soil negative charges. The incorporation of nitrogen fertilizer to the soil may decrease $\mathrm{NH}_{3}$ volatilization by up to $90 \%$ (Ceretta et al., 2002; Ernani et al., 2003).

Gott et al. (2014) found that by incorporating nitrogen fertilizer to the soil, the losses are lower. However, this practice is not widely used by farmers in nitrogen fertilization, either for lack of adequate equipment for incorporation, for damage that this incorporation can promote in the root system, or by increased application cost.

Ernani et al. (2003) observed that with the surface application of urea, in sandy soil as well as loamy, $\mathrm{NH}_{3}$ losses increased from 15.7 to $29.3 \%$ by volatilization in relation to its incorporation, regardless of the black oat crop residue management, soil texture, soil organic matter content (SOM) and soil CEC.

However, it is important to note that even the sources with associated technologies were more efficient when 
Table 1. Average values of cumulative total $\mathrm{N}-\mathrm{NH}_{3}$ losses via volatilization per nitrogen source application under different managements and application times.

\begin{tabular}{|c|c|c|c|c|c|c|}
\hline \multirow{3}{*}{ Sources } & \multicolumn{3}{|c|}{ Surface N } & \multicolumn{3}{|c|}{ Incorporated $\mathrm{N}$} \\
\hline & $\mathrm{T} 1$ & $\mathrm{~T} 2$ & T3 & $\mathrm{T} 1$ & $\mathrm{~T} 2$ & $\mathrm{~T} 3$ \\
\hline & \multicolumn{6}{|c|}{ 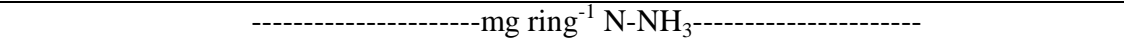 } \\
\hline $\mathrm{CU}$ & 8.04 & 7.22 & 5.78 & 5.60 & 4.59 & 3.85 \\
\hline UZ & 7.53 & 7.01 & 4.28 & 5.16 & 4.90 & 2.90 \\
\hline US & 7.84 & 6.71 & 5.10 & 5.01 & 4.86 & 4.51 \\
\hline $\mathrm{U}_{\mathrm{NBPT}}$ & 9.48 & 8.30 & 5.72 & 7.52 & 3.50 & 2.43 \\
\hline $\mathrm{OU}$ & 10.56 & 10.03 & 6.84 & 9.99 & 8.90 & 4.78 \\
\hline Time Averages & 8.69 & 7.85 & 5.54 & 6.65 & 5.35 & 3.69 \\
\hline Management Averages & & 7.36 & & & 5.23 & \\
\hline
\end{tabular}

CU: Convencional ureia; UZ: Urea combined with mineral zeolite; US: Urea coated with elemental sulfur; $\mathrm{U}_{\mathrm{NBPT}}$ : Urea coated with NBPT; and OU: Urea combined with organic material; Time 1: $100 \%$ of the $\mathrm{N}$ dose applied at the beginning of the experiment; Time $2: 50 \%$ of the $\mathrm{N}$ dose initially applied and $50 \%$ after seven days; and Time $3: 33.4 \%$ of the $\mathrm{N}$ dose initially applied and two applications of $33.3 \%$ in two intervals of seven days; NBPT: N-(n-butyl) thiophosphate triamide.

Table 2. Average contrast between total $\mathrm{N}^{-\mathrm{NH}_{3}}$ losses per nitrogen source applications and different soil managements and application times.

Contrasts

\begin{tabular}{lccc}
\hline $\mathrm{C} 1$ & $\mathrm{C} 2$ & $\mathrm{C} 3$ & $\mathrm{C} 4$ \\
\hline$-0.57 * *$ & $2.81 * *$ & $0.67 * *$ & $0.37 *$
\end{tabular}

$\mathrm{C}_{1}=\mathrm{CU}$ vs (UZ + US + UNBPT + OU); $\mathrm{C}_{2}=\mathrm{OU}$ vs (UZ + US + $\mathrm{U}_{\mathrm{NBPT}}$ ); $\mathrm{C}_{3}=\mathrm{U}_{\mathrm{NBPT}}$ vs (US + UZ); C4 = US vs UZ; CU: Conventional Urea; UZ: Urea combined with mineral zeolite; US: Urea coated with elemental sulfur; $\mathrm{U}_{\mathrm{NBPT}}$ : Urea coated with NBPT; and OU: Urea combined with organic material (organomineral); NBPT: N-(nbutyl) thiophosphate triamide; ${ }^{\circ} *$ and ${ }^{* *}$, Significant at 10,5 and $1 \%$, respectively.

Table 3. Contrast between average total $\mathrm{N}-\mathrm{NH}_{3}$ losses per different managements adopted and nitrogen sources.

\begin{tabular}{lccccc}
\hline Contrast & $\mathrm{CU}$ & $\mathrm{UZ}$ & $\mathrm{US}$ & $\mathrm{U}_{\mathrm{NBPT}}$ & OU \\
\hline $\mathrm{C} 5$ & $2.33^{* *}$ & $1.95^{* *}$ & $1.76^{* *}$ & $3.34^{* *}$ & $1.25^{* *}$ \\
\hline $\mathrm{C}_{5}=$ Surface & management vs. Incorporated management; $\mathrm{CU}$ : Conventional urea; & UZ: Urea combined with mineral zeolite; US: Urea coated with elemental sulfur; $\mathrm{U}_{\mathrm{NBPT}}$
\end{tabular}

Urea coated with NBPT; and OU: Urea combined with organic material; $\mathrm{N}_{\mathrm{BPT}}$ : N-(n-butyl) thiophosphate triamide. ${ }^{\circ},{ }^{*}$ and $* *$, Significant at 10,5 and $1 \%$, respectively.

Table 4. Contrast between average total $\mathrm{N}-\mathrm{NH}_{3}$ losses per different application times adopted and the nitrogen sources.

\begin{tabular}{lcccccc}
\hline Contrasts & Managements & CU & UZ & US & $U_{\text {NBPT }}$ & OU \\
\hline \multirow{2}{*}{ C6 } & Sur. & $1.54^{* *}$ & $1.89^{* *}$ & $1.94^{* *}$ & $2.47^{* *}$ & $2.13^{* *}$ \\
& Inc. & $1.38^{* *}$ & $1.26^{* *}$ & 0.32 & $4.56^{* *}$ & $3.15^{* *}$ \\
\hline \multirow{2}{*}{ C7 } & Sur. & $1.44^{* *}$ & $2.73^{* *}$ & $1.61^{* *}$ & $2.58^{* *}$ & $3.19^{* *}$ \\
& Inc. & $0.74^{* *}$ & $2.00^{* *}$ & 0.35 & $1.07^{* *}$ & $4.12^{* *}$ \\
\hline
\end{tabular}

$\mathrm{C}_{6}=$ Time 1 vs. Time $2+$ Time 3. $\mathrm{C}_{7}=$ Time 2 vs Time 3 Inc. - Incorporated management, Sur - Surface management.; CU: Conventional urea; UZ: Urea combined with mineral zeolite; US: Urea coated with elemental sulfur; $\mathrm{U}_{\mathrm{NBPT}}$ : Urea coated with NBPT; and OU: Urea combined with organic material; $\mathrm{N}_{\mathrm{BPT}}$ : N-(n-butyl) thiophosphate triamide. ${ }^{\circ}, *$ and $* *$, Significant at 10,5 and $1 \%$, respectively.

Table 5. Coefficients of the logistic equation (time required to reach half the maximum $\mathrm{N}^{-\mathrm{NH}_{3}}\left(\mathrm{t}^{1 / 2}=-\mathrm{b} / \mathrm{c}\right)$ production per time $\mathrm{T} 1$, T2 and T3, using soil (IM) and surface (SM) management in 28 days.

\begin{tabular}{|c|c|c|c|c|c|c|c|c|c|c|c|c|c|}
\hline \multirow[b]{2}{*}{ Sources } & \multicolumn{3}{|c|}{$\mathrm{a}^{(1)}$} & \multicolumn{3}{|c|}{$\mathrm{b}^{(1)}$} & \multicolumn{3}{|c|}{$\mathrm{c}^{(1)}$} & \multirow[b]{2}{*}{$\mathrm{R}^{2}$} & \multicolumn{3}{|c|}{$t 1 / 2$} \\
\hline & $\mathrm{T} 1$ & $\mathrm{~T} 2$ & T3 & $\mathrm{T} 1$ & $\mathrm{~T} 2$ & $\mathrm{~T} 3$ & $\mathrm{~T} 1$ & $\mathrm{~T} 2$ & $\mathrm{~T} 3$ & & $\mathrm{~T} 1$ & $\mathrm{~T} 2$ & T3 \\
\hline & \multicolumn{13}{|c|}{ SM } \\
\hline $\mathrm{CU}$ & 7.83 & 7.10 & 6.12 & -8.84 & -5.72 & -5.42 & 0.86 & 0.51 & 0.36 & 0.99 & 10.27 & 11.28 & 14.93 \\
\hline UZ & 7.57 & 7.18 & 4.05 & -8.14 & -4.51 & -10.8 & 0.61 & 0.35 & 1.03 & 0.99 & 13.39 & 13.04 & 10.49 \\
\hline US & 7.96 & 6.79 & 5.10 & -8.00 & -4.22 & -4.05 & 0.54 & 0.35 & 0.38 & 0.99 & 14.92 & 12.15 & 10.86 \\
\hline $\mathrm{U}_{\mathrm{NBPT}}$ & 10.3 & 8.54 & 5.73 & -3.59 & -3.30 & -4.69 & 0.27 & 0.31 & 0.38 & 0.98 & 13.49 & 10.80 & 12.21 \\
\hline $\mathrm{OU}$ & 10.5 & 10.3 & 7.40 & -4.60 & -6.06 & -4.19 & 0.45 & 0.43 & 0.28 & 0.99 & 10.17 & 13.99 & 14.80 \\
\hline & \multicolumn{13}{|c|}{ IM } \\
\hline $\mathrm{CU}$ & 5.70 & 4.62 & 3.78 & -8.99 & -8.78 & -7.18 & 0.59 & 0.56 & 0.66 & 0.99 & 15.25 & 15.73 & 10.97 \\
\hline UZ & 5.13 & 4.59 & 2.99 & -9.52 & -6.66 & -6.47 & 0.65 & 0.79 & 0.44 & 0.99 & 14.69 & 8.42 & 14.80 \\
\hline US & 4.91 & 4.96 & 5.04 & -8.91 & -13.1 & -3.04 & 0.66 & 0.82 & 0.23 & 0.99 & 13.57 & 15.93 & 13.40 \\
\hline $\mathrm{U}_{\mathrm{NBPT}}$ & 7.41 & 3.39 & 2.39 & -11.2 & -9.00 & -6.18 & 0.82 & 0.66 & 0.44 & 0.99 & 13.61 & 13.67 & 14.13 \\
\hline $\mathrm{OU}$ & 10.0 & 9.22 & 4.84 & -8.81 & -6.41 & -8.98 & 0.65 & 0.46 & 0.60 & 0.99 & 13.46 & 14.00 & 14.94 \\
\hline
\end{tabular}

${ }^{(1)}$ logistic equation $\mathrm{Y}=\mathrm{a} /\left(1+\mathrm{e}^{-(\mathrm{b}+\mathrm{cx})}\right)$; IM = Icorporated management; $\mathrm{SM}=$ Surface management; Time 1: $100 \%$ of the $\mathrm{N}$ dose applied at the beginning of the experiment; Time 2: $50 \%$ of the $\mathrm{N}$ dose $\mathrm{i}$ initially applied and 50\% after seven days; and Time 3: $33.4 \%$ of the $\mathrm{N}$ dose initially applied and two applications of $33.3 \%$ in two intervals of seven days; NBPT: N-(n-butyl) thiophosphate triamide.; CU: Conventional urea; UZ: Urea combined with mineral zeolite; US: Urea coated with elemental sulfur; U $\mathrm{NBPT}_{\text {: }}$

Urea coated with NBPT; and OU: Urea combined with organic material; $\mathrm{N}_{\mathrm{BPT}}$ : N-(n-butyl) thiophosphate triamide. 
incorporated into the soil, volatilizing less $\mathrm{N}-\mathrm{NH}_{3}$, as noted in C5 (Table 3). This demonstrates improvement possibilities (refinement) of the technologies used in this work, such as improvements in the combinations and thicknesses of the coatings or mixtures (organic and inorganic) for the fertilizers. For fertilizer application times with their different managements, all sources behaved similarly (Table 4). When fertilization is parceled out, the $\mathrm{N}^{-\mathrm{NH}_{3}}$ volatilization decreases. These results corroborate Amado et al. (2002) and Silva et al. (2005) in which the nitrogen fertilizer parceling and application time constitute alternatives to increase $\mathrm{N}$ fertilizer efficiency by the crops and mitigate losses. This is supported by better use of $\mathrm{N}$, a result of synchronization between applications and the period of high nutrient demand. The C6 contrast (Table 4) shows that when parceling the nitrogen fertilizer application with different managements (surface and incorporated into the soil), $\mathrm{NH}_{3}$ losses via volatilization are minimized. Thus, the results obtained in this work with stabilized controlled release nitrogen fertilizer does not corroborate with what is indicated by Boman and Battikhi (2007), for whom the use of slow release nitrogen fertilizer reduces the need for parceling fertilizers.By parceling the application of the nitrogen sources in three times, independently of the management type adopted (surface and incorporated), the $\mathrm{NH}_{3}$ volatilization decreases (C7, Table 5). Wilson et al. (2009) demonstrated a reduction in the need to split $\mathrm{N}$ application when using coated urea, which was not observed in our study. The cumulative $\mathrm{NH}_{3}$ volatilization values as a function of collection time were adjusted to the logistic equation $\left[\mathrm{Y}=\mathrm{a} / 1+\mathrm{e}^{-(\mathrm{b}+\mathrm{cx})}\right.$ (Passos et al., 2007; Andrade et al., 2013). For all treatments (Table 6), in general, higher values for the $\mathrm{NH}_{3}$ saturation evolution (coefficient a) were observed for Time 1 (100\% of the $\mathrm{N}$ dose applied at the start of the experiment), indicating that this type of nitrogen fertilizer application favored greater volatilization, regardless of the management type. The cumulative production of volatilized $\mathrm{NH}_{3}$ adequately adjusted to the logistic growth function for all treatments (Table 5). The highest values for $\mathrm{NH}_{3}$ saturation evolution (coefficient a) were observed for the OU fertilizer, indicating that it has qualitative characteristics that favored its volatilization and / or a higher proportion of more easily volatile $\mathrm{NH}_{3}$, in both the surface, as well as in the incorporated managements. Parceling the $\mathrm{N}$ dose resulted in lower $\mathrm{N}-\mathrm{NH}_{3}$ capture values, regardless of the source applied. In this sense, Time 1 was superior to Time 3 .

For the surface management (SM) we observed higher coefficient $b$ values (longer to reach $\mathrm{NH}_{3}$ saturation) for fertilizer applications at different times (T1, T2, T3), reflecting its higher $\mathrm{NH}_{3}$ volatilization. This was not observed in the incorporated management (IM) of the fertilizer applied. There was little variation between the growth rate function (coefficient c) for both the SM and IM, suggesting that it was not very sensitive to qualitative variations between nitrogen fertilizer application times (Table 5). This fact apparently induced the same growth curve pattern. Higher $t^{1 / 2}$ values were found for the UZ, indicating that this fertilizer has a lower rate. It is inferred that the lower $\mathrm{N}$ loss rate volatilized in the form of $\mathrm{NH}_{3}$ can be related to the addition of zeolite (mineral) to the urea granules, via coating or granulation of a mixture of the powdered materials, reducing ammonia losses by volatilization when the fertilizer was applied to the soil.

\section{Materials and Methods}

\section{Soil characterization}

For this experiment, samples were collected from a Latossolo Vermelho-Amarelo is dystrophic (oxisol) (Embrapa, 2013) at a depth of $20-40 \mathrm{~cm}$. Once collected, the samples were air dried, declodded, and passed through a $2.0 \mathrm{~mm}$ sieve to obtain fine air-dried soil (FADS).

The chemical and physical analyzes of the soil samples, performed according to Embrapa (1997) and Almeida et al. (2012), respectively, presented the following soil attributes: $\mathrm{pH}\left(\right.$ in $\left.\mathrm{H}_{2} \mathrm{O}\right)=4.80 ; \mathrm{P}=6.34 \mathrm{mg} \mathrm{dm}^{-3} ; \mathrm{K}=14.00 \mathrm{mg} \mathrm{dm}^{-3}$; $\mathrm{Ca}=0.70 \mathrm{cmol}_{\mathrm{c}} \mathrm{dm}^{-3} ; \mathrm{Mg}=0.70 \mathrm{cmol}_{\mathrm{c}} \mathrm{dm}^{-3} ; \mathrm{Al}^{3+}=0.25$ $\mathrm{cmol}_{\mathrm{c}} \mathrm{dm}^{-3} ; \mathrm{H}+\mathrm{Al}=4.29 \mathrm{cmol}_{\mathrm{c}} \mathrm{dm}^{-3} ;$ Sum of Bases $=1.44$ $\mathrm{cmol}_{\mathrm{c}} \mathrm{dm}^{-3} ;$ CEC capacity $=5.73 \mathrm{cmol}_{\mathrm{c}} \mathrm{dm}^{-3} ; \mathrm{CECt}=1.69$ $\mathrm{cmol}_{\mathrm{c}} \mathrm{dm}^{-3} ; \mathrm{V}=25.13 \% ;$ Sand $=296 \mathrm{~g} \mathrm{~kg}^{-1} ;$ Silt $=32 \mathrm{~g} \mathrm{~kg}^{-1}$; Clay $=672 \mathrm{~g} \mathrm{~kg}^{-1}$.

Different $\mathrm{N}$ sources were added to soil samples at different application and managements times (incorporated and not incorporated). The $\mathrm{N}$ sources used were: conventional urea $\mathrm{CU}$; urea combined with mineral zeolite - UZ; elemental sulfur coated urea - US; NBPT coated urea (N-(n-Butyl) triamide) - $\mathrm{U}_{\mathrm{NBPT}}$; and urea combined with organic material (filter cake) - OU. The $\mathrm{N}$ dose used was $75 \mathrm{mg} \mathrm{dm}^{-3}$, considering the volume of soil used.

\section{Experimental design}

The treatments followed a factorial $5 \times 3 \times 2$ where the factors studied were: five $\mathrm{N}$ sources $\left(\mathrm{CU}, \mathrm{UZ}, \mathrm{US}, \mathrm{U}_{\mathrm{NBPT}}\right.$, OU) $\mathrm{x}$ three application times, Time 1 being: $100 \%$ of the $\mathrm{N}$ dose applied at the beginning of the experiment; Time 2: $50 \%$ of the $\mathrm{N}$ dose applied at the beginning of the experiment and $50 \%$ after seven days; and Time 3: $33.4 \%$ of the $\mathrm{N}$ dose applied at the beginning of the experiment and two applications of $33.3 \%$ in two intervals of seven days; and two types of managements (surface application and application incorporated to two centimeters). The experiment was arranged in a randomized block design (RBD) with three replications.

Soil samples $\left(2 \mathrm{dm}^{3}\right)$ were placed in plastic bags for liming by $\mathrm{Al}^{3+}$ neutralization and elevated $\mathrm{Ca}^{2+}+\mathrm{Mg}^{2+}$ concentration method (Alvarez V. and Ribeiro, 1999). Soil moisture was then adjusted to $60 \%$ of field capacity (Reichardt, 1988). After 21 days of incubation, the soil was air dried declodded and sieved in a $2 \mathrm{~mm}$ seive (FADS) for mounting the experiment.

Experimental units were PVC rings, $10 \mathrm{~cm}$ in diameter and $10 \mathrm{~cm}$ high. These rings were filled with $0.5 \mathrm{dm}^{3}$ of FADS samples. The rings then received phosphorus $\left(300 \mathrm{mg} \mathrm{dm}^{-3}\right)$ and potassium $\left(150 \mathrm{mg} \mathrm{dm}^{-3}\right.$ ) application (Novais et al., 1991) and water to reach $60 \%$ of the field capacity. After application, the rings were maintained at a temperature of $25^{\circ} \mathrm{C}$ for three days to acclimate soil biota and for urease production. After this period, the nitrogen fertilizers were applied to the soil at $75 \mathrm{mg} \mathrm{dm}^{-3}$ of $\mathrm{N}$, respecting the times and managements adopted. Immediately after the nitrogen fertilizer applications, a static-free, semi-open collection chamber (SALE) (Araújo et al., 2009) was coupled at the top of each ring to capture the ammonia released by the fertilizer. The assembly and conduction of the experiment were carried out under a controlled temperature $\left(25^{\circ} \mathrm{C}\right)$. 
The experiment was conducted for 25 days, with the collection and exchange of the foams conducted on the $2^{\text {nd }}$, 4th, 7th, 9th, 11th, 14th, 16th, 18th, 21st, 23rd and 25th days after the start of the experiment. After each collection, the ammonia was quantified according to Silva et al. (2010).

\section{Data analysis}

The results were submitted to analysis of variance using the SAEG program (SAEG, 2007) described by Euclydes (1983) and the qualitative effects (sources, times and management) were broken down in contrasts and the $\mathrm{NH}_{3}$ volatilization curve (cumulative $\mathrm{N}-\mathrm{NH}_{3}$ production) with the incubation time, was adjusted in the logistic equation $\left[\mathrm{Y}=\mathrm{a} / 1+\mathrm{e}^{-(\mathrm{b}+\mathrm{cx})}\right]$ (Passos et al., 2007; Andrade et al., 2013).

Parameter "a" represents the saturation curve, which is associated with the maximum $\mathrm{NH}_{3}$ accumulation volatilized; " $b$ " represents the position parameter which shifts the curve horizontally, and the greater its value the longer the time to reach the peak $\mathrm{NH}_{3}$ volatilized; and "c" represents the parameter related to the function growth rate and which is directly associated with the $\mathrm{NH}_{3}$ volatilization. Through these coefficients it was possible to estimate the time required to reach half-maximal $\mathrm{NH}_{3}$ emission $\left(\mathrm{t}^{1 / 2}\right)$. The $\mathrm{t}^{1 / 2}$ indicates the time (days) that the inflexion curve occurred.

\section{Conclusions}

Urea combined with mineral zeolite (UZ) showed lowest $\mathrm{NH}_{3}$ volatilization values in relation to the other sources used. The ascending order of $\mathrm{N}-\mathrm{NH}_{3}$ volatilization was: $\mathrm{UZ}<$ $\mathrm{US}<\mathrm{CU}<\mathrm{U}_{\mathrm{NBPT}}<\mathrm{OU}$, regardless of the time and management adopted. The incorporation of nitrogen fertilizers to the soil reduced losses by volatilization, even for fertilizers with associated technology. The parceling of nitrogen fertilization reduces nitrogen losses through volatilization as $\mathrm{NH}_{3}$, despite the use of fertilizers with associated technology.

\section{Acknowledgement}

To the Coordenação de Aperfeiçoamento de Pessoal de Nível Superior (CAPES) for the grant awarded during the Master's course and to the Fundação de Amparo à Pesquisa do Espírito Santo (FAPES).

\section{References}

Almeida RF, Sanches BC (2013) Fertilizantes nitrogenados com liberação lenta e estabilizada na agricultura. Rev Verde Agroecologia Desenvolv Sustent. 7(5):31-35.

Almeida BG, Donagemma GK, Ruiz HA, Braida JA, Viana JHM, Reichert JMM, Oliveira LB, Ceddia MB, Wadt PGS, Fernandes RBA, Passos RR, Dechen SCF, Klein VA, Teixeira WG (2012) Padronização de métodos para análise granulométrica no Brasil. Embrapa Solos. 11p.

Alvarez V VH, Ribeiro AC (1999) Calagem. In: Ribeiro AC, Guimarães PTG, Alvarez V VH. Recomendações para o uso de corretivos e fertilizantes em Minas Gerais - $5^{\text {a }}$ aproximação. Viçosa, MG. p. 43-60

Amado TJC, Mielniczuk J, Aita C (2002) Recomendação de adubação nitrogenada para o milho no RS e SC adaptada ao uso de culturas de cobertura do solo, sob sistema plantio direto. Rev Bras Ciênc Solo. 26:241-248.

Andrade FV, Mendonça EDS, Silva IRD (2013) Organic acid adsorption and mineralization in oxisols with different textures. Rev Bras Ciênc Solo. 37(4):976-985.
Araújo ES, Marsola T, Miyazawa M, Soares LHB, Urquiaga S, Boddey RM, Alves BJR, (2009) Calibração de câmara semiaberta estática para quantificação de amônia volatilizada do solo. Pesq Agropec Bras. 44(7):769-776.

Bennett E (1996) Slow release fertilizers. The Virginia Gardener Newsletter, Virginia Tech (USA). 11(4).

Boman BJ, Battikhi AM (2007) Growth, evapotranspiration, and nitrogen leaching from young lysimeter-grown orange trees. J Irrig Drain Eng. 133(4):350-358.

Bono JAM, Setti JCA, Spekken SSP (2006) O nitrogênio protegido como alternativa de fertilizante para o uso no plantio da cultura do algodão. Ensaios e C. 10:39-45.

Cahill S, Osmond D, Weisz R, Heiniger R (2010) Evaluation of alternative nitrogen fertilizers for corn and winter wheat production. Agron J. 102(4):1226-1236.

Cantarella H, Trivelin PCO, Contin TLM, Dias FLF, Rossetto R, Marcelino R, Coimbra RB, Quaggio JA (2008) Ammonia volatilisation from urease inhibitor-treated urea applied to sugarcane trash blankets. Sci Agric. 65(4):397401.

Carmona G, Christianson CB, Byrnes BH (1990) Temperature and low concentration effcts of the urease inhibitor N-(n-butyl) thiophosphoric triamide (nBTPT) on ammonia volatilization from urea. Soil Biol Biochem. 22(7):933-937.

Carneiro LF, Silva DRG, Cancellier EL, Leite RDC, Soares DDA (2014) Agronomic efficiency of polymer-coated nitrogen fertilizers in common bean crop in brazilian Midwest. J Biotechnol Biodivers. 5(3).

Ceretta CA, Basso CJ, Flecha AMT, Pavinato PS, Vieira FCB, Mai MEM (2002) Manejo da adubação nitrogenada na sucessão aveia preta/milho, no sistema plantio direto. Rev Bras Ciênc Solo. 26:163-171.

Connel JH, Meyer RD, Meyer JL, Carlson RM (1979) Gaseous ammonia losses following nitrogen fertilization. Calif Agric. 33:11-12.

Embrapa (1997) Manual methods of analysis of soils. $2^{\text {th }}$ Edition. Rio de Janeiro: Embrapa. 212p.

Embrapa Solos (2013). Sistema brasileiro de classificação de solos. Rio de Janeiro: Embrapa. 353p.

Ernani LSPR, Lech VA, Rampazzo C (2003) Volatilização de $\mathrm{N}-\mathrm{NH}_{3}$ em decorrência da forma de aplicação de ureia, manejo de resíduos e tipo de solo, em laboratório. Cienc Rural. 33(4):687-692.

Euclydes RF (1983) Manual de utilização do programa SAEG (Sistema para Análises Estatísticas e Genéticas). Viçosa: UFV. 53p.

Fernandes FCS, Buzetti S, Arf O, Andrade JAC (2005) Doses, eficiência e uso de nitrogênio por seis cultivares de milho. RBMS. 4(2):195-204.

Frazão JJ, Silva AR, Silva VL, Oliveira VA, Corrêa RS (2014) Fertilizantes nitrogenados de eficiência aumentada e ureia na cultura do milho. Rev Bras Eng Agríc Ambient. 18(12):1262-1267.

Gott RM, Sichocki D, Aquino LA, Xavier FO, Santos LPD, Aquino RFBA (2014) Fontes e épocas de aplicação de nitrogênio no milho safrinha. RBMS. 13:24-34.

Khalil MI, Schmidhalter U, Gutser R (2006) $\mathrm{N}_{2} \mathrm{O}, \mathrm{NH}_{3}$ and $\mathrm{NO}_{\mathrm{x}}$ emissions as a function of urea granule size and soil type under aerobic conditions. Water Air Soil Pollut. 175(14):127-148.

Kreimeyer A, Eckes P, Fischer C, Lauke H, Schuhmacher P (2015) We Create Chemistry for a Sustainable Future: Chemistry Creates Sustainable Solutions for a Growing World Population. Angew Chem Int Ed Engl. 54(11):31783195. 
Lara Cabezas WAR, Korndörfer GH, Motta SA (1997) Volatilização de $\mathrm{N}_{-} \mathrm{NH}_{3}$ na cultura de milho: I. Efeito da irrigação e substituição parcial da ureia por sulfato de amônio. Rev Bras Ciên Solo. 21(3):481-487.

Lara Cabezas WAR, Trivelin PCO, Boaretto AE (1992) Efeito do tamanho de grânulo e relação N/S da ureia aplicada em superfície na volatilização de amônia sob diferentes umidades iniciais do solo. Rev Bras Ciên Solo. 16(3):409-413.

Lara Cabezas WAR, Trivelin PCO, Bendassolli JA, Gascho GJ (1999) Calibration of a semi-open static collector for determination of ammonia volatilization from nitrogen fertilizers. Comm Soil S. 30(3-4):389-406.

Lara Cabezas WAR, Trivelin PCO, Kornodôrf GH, Pereira S (2000) Balanço da adubação nitrogenada sólida e fluida de cobertura na cultura do milho em sistema plantio direto no Triângulo Mineiro. Rev Bras Ciên Solo. 24(4):363-376.

Medina LC, Obreza TA, Sartain JB, Rouse RE (2008) Nitrogen release patterns of a mixed controlled-release fertilizer and its components. HortTechnology. 18(3):475480.

Mumpton FA (1999) La roca magica: uses of natural zeolites in agriculture and industry. Proc Natl Acad Sci. 96(7):3463-3470.

Nash PR, Nelson KA, Motavalli PP, Anderson SH (2015) Corn Yield Response to Managed Drainage and PolymerCoated Urea. Agron J. 107(2):435-441.

Novais RF, Neves JCL, Barros NF, Oliveira AJ, Garrido WE, Araújo JD, Lourenço S (1991) Ensaio em ambiente controlado. Métodos de pesquisa em fertilidade do solo. Embrapa-SEA. 189-254.

Passos RR, Ruiz HA, Mendonça EDS, Cantarutti RB, Souza AD (2007). Substâncias húmicas, atividade microbiana e carbono orgânico lábil em agregados de um Latossolo Vermelho distrófico sob duas coberturas vegetais. Rev Bras Ciên Solo. 31(5):1119-1129.

Peng X, Maharjan B, Yu C, Su A, Jin V, Ferguson RB (2015) A laboratory evaluation of ammonia volatilization and nitrate leaching following nitrogen fertilizer application on a coarse-textured soil. Agron J. 107(3):871-879.

Reichardt K (1988) Capacidade de campo. Rev Bras Ciên Solo. 12(2):211-216.

Rodrigues MB, Kiehl JC (1986) Volatilização de amônio após emprego de ureia em diferentes doses e modos de aplicação. Rev Bras Ciên Solo. 10:37-43.

SAEG Sistema para Análises Estatísticas, Versão 9.1 (2007) Fundação Arthur Bernardes - UFV - Viçosa.

Sato S, and Morgan KT (2008) Nitrogen recovery and transformation from a surface or sub-surface application of controlled-release fertilizer on a sandy soil. J Plant Nutr. 31(12):2214-2231.

Sengik E, and Kiehl JC (1995) Efeito de resíduos orgânicos e do fosfato monocálcico na volatilização de amônia em terra tratada com ureia. Rev Bras Ciên Solo. 19(2):321-326.

Silva DF, Andrade CLT, Simeone MLF, Amaral TA, Castro LA (2010) Análise de nitrato e amônio em solo e água. Sete Lagoas: Embrapa Milho e Sorgo. 55p.

Silva AJ, Lima MAJ, Ferreira NCM, Fraga VS (1995) Perdas de amônia por volatilização proveniente da ureia aplicada a solos dos trópicos úmidos. Rev Bras Ciên Solo. 19:141144 .
Silva EC, Buzetti S, Guimarães GL, Lazarini E, Sá ME (2005) Doses e épocas de aplicação de nitrogênio na cultura do milho em plantio direto sobre Latossolo Vermelho. Rev Bras Ciên Solo. 29(3):353-362.

Stafanato JB, Goulart RS, Zonta E, Lima E, Mazur N, Pereira CG, Souza HN (2013) Volatilização de amônia oriunda de ureia pastilhada com micronutrientes em ambiente controlado. Rev Bras Ciên Solo. 37(3):726-732.

Tasca FA, Ernani PR, Rogeri DA, Gatiboni LP, Cassol PC (2011) Volatilização de amônia do solo após a aplicação de ureia convencional ou com inibidor de uréase. Rev Bras Ciên Solo. 35(2):493-502.

Torma S, Vilcek J, Adamisin P, Huttmanova E, Hronec O (2014) Influence of natural zeolite on nitrogen dynamics in soil. Turk J Agric For. 38(5):739-744

Trenkel ME (2010) Slow and controlled-release and stabilized fertilizers: An Option for Enhancing Nutrient Efficiency in Agriculture. 2. ed. Paris: IFA. 163p.

Volk MG (1959) Volatile loss of ammonia following surface application of urea to turf of bare soils. Agron J. 51(12):746-749

Wang S, Zhao X, Xing G, Yang Y, Zhang M, Chen H (2015) Improving grain yield and reducing $\mathrm{N}$ loss using polymercoated urea in southeast China. Agron Sustainable Dev. 35(3):1103-1115.

Werneck CG, Breda FA, Zonta E, Lima E, Polidoro JC, Balieiro FDC, Bernardi ACDC (2012) Ammonia volatilization from urea with natural zeolite. Pesqui Agropec Bras. 47(3):466-470.

Wilson ML, Rosen CJ, Moncrief JF (2009) Potato response to polymer-coated urea on an irrigated, coarse textured soil. Agron J. 101(4):897-905.

Yang YC, Zhang M, Zheng L, Cheng DD, Liu M, Geng YQ (2011) Controlled Release Urea Improved Nitrogen Use Efficiency, Yield, and Quality of Wheat. Agron J. 103(2):479-485.

Zavaschi E, Faria LA, Vitti GC, Nascimento CAC, Moura TA, Vale DW, Mendes FL, Kamogawa MY (2014) Ammonia volatilization and yield components after application of polymer-coated urea to maize. Rev Bras Ciên Solo. 38(4):1200-1206. 